\title{
Observing the Impact of Confinement on the Rearing of Land Crabs
}

\author{
Joyce Mamle Mawusi Obubuafo (Corresponding author) \\ Department of Agro Enterprise Development, Faculty of Applied Sciences and \\ Technology, Ho Technical University, Ho-Ghana \\ E-mail:mamlejo1@yahoo.com
}

Grace Denny Doku

Department of Agro Enterprise Development, Faculty of Applied Sciences and

Technology, Ho Technical University, Ho-Ghana

E-mail: avliaman@yahoo.com

Mawutor K. Glover

E-mail:mgloverk@yahoo.com

Margaret Aba Sam Hagan

Department of Agropreneurship, Faculty of Entrepreneurship and Enterprise

Development, Kumasi Technical University, Kumasi.

E-mail: aba_hagan13@yahoo.com

Received: May 29, 2020 Accepted: June 17, 2020 Published: June 30, 2020

doi:10.5296/jfi.v4i1.17286 URL: http://dx.doi.org/10.5296/jfi.v4i1.17286

\begin{abstract}
The study observed the impact of confinement on the rearing of land crabs in an attempt to produce crabs that can be consumed without having to worry about their unwholesomeness, traceability and also the possibility of producing crabs all year round.
\end{abstract}




\section{MInstitute ${ }^{\text {Mink }}$}

Two species of the land crabs were observed for five months: 35 Rainbow land crabs, obtained from Ada, a suburb of the Greater Accra Region of Ghana and 20 Blue land crabs obtained from Sokode, a suburb of the Volta Region of Ghana. the study investigated the 55 land crabs by observing their coexistence, feeding and reproduction in confinement. Dealers in land crabs and other resource persons who had some experience with land crabs where interviewed. At the beginning of the study, the average weight of a male rainbow land crab was 3.3 pounds and that of a female was 3.0 pounds. However, at the end of the study the average weight recorded for the male Rainbow land crab was 5.7poundsand that of the female was 5.4pounds. The number of rainbow land crabs that died during the cause of the study was 7 and 12 escaped resulting in 16 of them remaining by the end of the study. Six of the crabs lost their appendages, one female moulted, 4 female crabs produced eggs and spawned. The only female Blue land crab that survived produced eggs in confinement but later died after three weeks from the commencement of the study. Results of the study showed that the Rainbow land crabs are hardier as compared to the Blue land crabs and thus, the best specie that can be reared in confinement. The Rainbow land crabs can be reared in confinement for a minimum period of five months if the confined area is darkened and hideout accessories provided. The crabs can be fed on a range of diets, from fish, vegetables to leftovers from the kitchen. However, the crabs seem to prefer sugar cane, palm fronds and fruits. The female Rainbow land crabs are capable of spawning in confinement when provided with the right conditions and environment.

Keywords: Rainbow land crab, Blue land crab, confinement, rearing

\section{Introduction}

Crabs are a delicacy in Ghana enjoyed by majority of the population, mostly inhabitants along the coasts and rivers. It is reported that crabs contain high levels of protein and essential minerals good for persons recuperating from an illness and for maintaining pregnancy. Some crab dishes prepared in Ghana are "apapransa", "kotonshi", crab palmnut soup and okro soup among others. Two species of land crabs indigenous to Ghana are the blue land crab (Cardisoma guanhumi) which can be found in Ho and its environs in the Volta Region and the rainbow land crabs (Cardisoma armatum) also found in Ada, in the Greater Accra Region of Ghana (Bright et. al., 1972; Ugbomeh and Bajor, 2015). These are the land crabs commonly found in our markets. Land crabs are mostly exploited by being captured directly from the wild and commercialized thus not only bring the crabs to the verge of extinction but poses danger to the environment as well (Dessuassi, et. al., 2018). Most of the crabs sold to the Ghanaian public are captured directly from the wild such as swampy or waterlogged areas with thick overgrowth, along streams, rivers and coastal shores (Oduro, et. al., 2001). Due to human activities that affect our water bodies such as the use of agrochemicals that find their way into water bodies and illegal chemicals used in fishing in these water bodies, crabs can be contaminated with heavy metals like arsenic contained in these chemicals (Mbeh, 2019; Zhang, 2018).Crabs can also consume poisonous fruits that can cause ulcers and lesions to those who consume them (Lloyd, 2001). The land crab's ability to move to multiple sites, its preference to inhabit lower laying aquatic areas and their dietary habits make them reservoirs to different bacteria species such as Salmonella, Escherichia coli, 


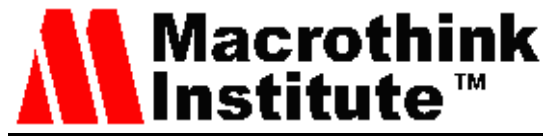

Klebsiella, Citrobacter, and Pseudomonas all of which are pathogenic to humans (Amadi, et. al., 2015). Crabs brought indirectly from the source of collection without first detoxifying them poses health problems to those who consume them (Hill, 2001; Lloyd, 2001). This unhealthy commercialization of the wild land crabs focuses on a significant economic activity, crab farming. Crab farming could provide additional income generating opportunity as a means of alleviating poverty and in the process conserving the environment (Mallen, 2011; Amadi et al., 2015).In order that consumers can purchase land crabs bred commercially without having to worry about how safe the crab is for consumption, this study focuses on observing the impact of confinement on the rearing of land crabs by investigating the following objectives: determining housing structures conducive for rearing land crabs; observing the impact of closeness of the crabs in a confined area; observing the possibility of female crabs reproducing in confinement and determining the best feed for the crabs.

Established Crab farms are not common in Ghana as such, this study of rearing land crabs is a way of initiating the establishment of such an enterprise in the country thereby, minimizing the problems of marketing of unwholesome land crabs to the Ghanaian public, the ability to trace the source of the crabs being purchased if the need of verification arises, conserving the environment since mangroves serve as profitable source of resources like fish, medicine, aside crabs (Alves, et. al., 2005) and the creation of employment since crabs serve as a major food source not only for Ghanaians but for inhabitants along the Gulf of Guinea, between Cote d'Ivoire and Nigeria and other parts of the world. Thus land Crab farming can serve as an export opportunity.

\section{Literature Review}

\subsection{Biology of Land Crabs}

The blue land crab grows roughly $127 \mathrm{~mm}$ wide and $102 \mathrm{~mm}$ long, weighing $400 \mathrm{~g}$ on average, though the males are generally larger than the females. As a juvenile, it is typically tan or brown in color with orange legs. As an adult, its coloring ranges from blue to violet, though some females are white or ashy gray. Its body, protected by a smooth carapace, consists of a cephalothorax and abdomen (Hill, 2001). Connected to its cephalothorax are five pairs of biramous appendages covered with tactile setae, each of which are sturdy and longer than the width of the cephalothorax. At its front are two pairs of antennae and two pincers, one larger than the other. The larger pincer in males can reach $300 \mathrm{~mm}$ in length. The blue land crabs are bilaterally symmetrical. (Burggren \& McMahon, 1988; Hill, 2001; Lloyd, 2001). The rainbow crabs are said to originate from coastal regions of Africa (Bright et. al., 1972). In Ghana, they can be found in the sandy areas of the greater Accra region, particularly, Ada. They are found close to the banks of rivers, cultivated areas adjacent to permanent sources of brackish or sea water. They are said to be nocturnal scavengers that feed on palm nuts, coconuts, dead fish and scraps of vegetation (Clake, 2005). They are also known to be cannibalistic. Even though they spend most of their life on land, the females return to the ocean to spawn (Ugbomeh \& Bajor, 2015). It is said that in confinement, life expectancy of crabs is a matter of how well they are cared for (Shelley et.al. 2011). 


\subsection{Importance of Crab Farming}

Crab farming is very important in that the natural habitat of land crabs due to human activities, are contaminated thus making consumption of these crabs a critical pathway to exposure of such contaminants to humans. Tissues of aquatic foods exposed to contaminants have the tendency to absorb as high as $90 \%$ of such substances making the food harmful to consumers (Wang et al., 2020). Some contaminates that pollute the habitats of crabs that poses health problems to consumers include plastics that are ingested by the crabs thus ending up in their guts and when consumed by humans poses health problems (Watts, et. al., 2015). Crabs from the wild could also serve as carriers of microbes that may cause health problems to consumers (Amadi et al., 2015). Aside contaminating the habitats of crabs, human activities can also disrupt the ecosystem of such habitats and not only are they homes for crabs but for other important life forms. Establishing a crab farm will serve as a conservation initiative to help reduce the rate at which the habitats are exploited (Carney, 2016). Crab farming can also serve as a profitable and viable venture for domestic income generation and for exports (Salam et al., 2012; Petersen et al, 2011; Sathiadhas \& Najmudeen, 2004 ).

\section{Methodology}

An observational research (case study) was initiated on February $28^{\text {th }}, 2016$ where the behavior of two species of land crabs were observed in confinement with the help of a camera and measuring scale.The study was carried out in Tema, in the Greater Accra Region of Ghana. The crabs, Rainbow land crabs, 35 in number, 23 females and 12 males were purchased from crab dealers in Ada, a town in the greater Accra region of Ghana and 20 Blue land crabs made up of 9 females and 11 males were obtained from Sokode in the Volta Region of Ghana. It is expected that some of the crabs would die in the initial stages of the study due to handling during hunting and transportation (Vosjoli, 2011), as such, crabs were acclimatized for about a week before the actual study began.

A pot and a wooden box were used as housing structures for the land crabs. The rainbow crabs were housed in the wooden box and the blue land crabs were housed in the pot. The wooden box had dimensions of width $60 \mathrm{~cm}$, length of $150 \mathrm{~cm}$ and a height of $60 \mathrm{~cm}$ with a lid of mesh to let in light and serve as an opening for ventilation. The pot had a circumference of $190 \mathrm{~cm}$ and a height of $60 \mathrm{~cm}$ with holes drilled around the base to allow excess water to drain out leaving a shallow puddle at the bottom for the crabs to get in and out easily. An earthen ware dish served as a lid for the pot since it is important for the housing structures to have a secure lid to prevent escapes. Some cage accessories such as rough rocks, leaves and branches were placed in the structures to provide stimulating climbing exercise for the crabs. Broken earthen ware and poly vinyl chloride (PVC) pipes with holes carved in them were placed at vantage points in the housing structures to serve as hideouts for the crabs. Hollow coconut shells were also placed in the housing structure as alternative hideouts.In an attempt to avoid soil contaminated with chemicals, the housing structures had beach sand obtained from Sakumono beach in the Greater Accra Region with leaves and grass as substrates. During the study, in order to provide that ambient temperature, the structures were placed in a shady area. 
Regular misting was carried out to keep the substrates and the housing structure area damp and to help keep humidity up to the required conditions.

Tap water stored in a container and left to stand for a minimum of 48 hours was provided for the crabs. The water was kept clean and fresh with regular changes and later sea water in shallow plastic containers for the female Rainbow land crabs to spawn in after observing that the females with eggs needed larger containers to hold more volumes of water to enable them spawn effectively.

Traders of crab in Tema, Ada and Ho markets and resource persons with experience in crabs were randomly selected and interviewed on the housing and feeding of the crabs. The interviews conducted and the fact that crabs are omnivores that eat both plant and animal (Ugbomeh \& Bajor, 2015) informed the diet fed to the crabs during the study. The main diet offered to the land crabs were palm fronds, palm fruits, anchovies and sugarcane. Occasionally, fresh vegetables, fruits, yam peels, cassava peels were also provided. Spoiled or moldy food may lead to the crab's death (Vosjoli ,2011) as such, any uneaten portions of food going bad were removed after a week to prevent unsanitary conditions.

It was further realized from the interview conducted that it was best not to handle crabs unless necessary. During the study crabs were handled at list once in a month, mostly when they were being weighed. The design of the wooden housing structure for the crabs had enough room to work around the crabs during feeding and cleaning without causing much disturbance to them. The pot, on the other hand, required that the crabs were transferred to another container for it to be cleaned.

Four recordings of the crabs' weights were taken: the initial weight recordings were taken a day after the crabs arrived at the study site, the next recording was taken a month after the initial recording, the third was three months later and the final was taken five months after the initial recording.

\section{Results and Discussion}

The study lasted for five months. During this period, out of the 35 rainbow crabs under study, 7 died and 12 escaped. After a month, the total number of Rainbow crabs under study dropped to 27 , after three months, the number dropped to 25 and at the time of the final reading, the total number of rainbow crabs under study was 16 (Table: 1 ).

Table 1 shows a descriptive statistic of the recorded weights of the Rainbow crabs. The initial average weight of a female crab was 3.0 pounds with a minimum weight of 2.0 pounds and a maximum weight of 4 pounds with majority of the females weighing 3.0 pounds. The average weight of a male Rainbow land crab was 3.3 pounds with the heaviest male weighting 4 pounds and the least weighting 2.0 pounds. However, majority of the males weighed 4.0 pounds. The average weight of a female Rainbow land crab after a month on arrival at the study site was 5.6 pounds with a minimum weight of 4.0 pounds and a maximum weight of 8.0 pounds with majority of the females weighing 6.0 pounds. The average weight of a male rainbow crab then was 5.6 pounds with the heaviest male weighting 8.0 pounds and the list weighting 4.0 pounds. However, majority of the males weighed 5.0 pounds. 
Table 1. Descriptive statistics of the weights of Rainbow land crabs in Pounds

\begin{tabular}{|c|c|c|c|c|c|c|c|c|}
\hline \multirow{2}{*}{ Description } & \multicolumn{2}{|c|}{$\begin{array}{l}\text { Initial reading } \\
\text { after one day }\end{array}$} & \multicolumn{2}{|c|}{$\begin{array}{l}\text { Reading after a } \\
\text { month }\end{array}$} & \multicolumn{2}{|c|}{$\begin{array}{l}\text { Reading after } \\
\text { three months }\end{array}$} & \multicolumn{2}{|c|}{$\begin{array}{l}\text { Reading after } \\
\text { five months }\end{array}$} \\
\hline & Male & Female & Male & Female & Male & Female & Male & Female \\
\hline Mean & 3.33 & 2.95 & 5.60 & 5.59 & 5.70 & 5.27 & 5.71 & 5.44 \\
\hline Median & 3.50 & 3.00 & 5.00 & 6.00 & 6.00 & 5.00 & 6.00 & 5.00 \\
\hline Mode & 4.00 & 3.00 & 5.00 & 6.00 & 6.00 & 5.00 & 5.00 & 5.00 \\
\hline $\begin{array}{l}\text { Standard } \\
\text { deviation }\end{array}$ & 0.78 & 0.49 & 1.35 & 1.00 & 0.82 & 0.80 & 0.76 & 0.53 \\
\hline $\begin{array}{l}\text { Sample } \\
\text { variance }\end{array}$ & 0.61 & 0.24 & 1.82 & 1.01 & 0.68 & 0.64 & 0.57 & 0.28 \\
\hline Range & 2.00 & 20 & 4.00 & 4.00 & 3.00 & 3.00 & 2.00 & 1.00 \\
\hline Minimum & 2.00 & 2.00 & 4.00 & 4.00 & 4.00 & 4.00 & 5.00 & 5.00 \\
\hline Maximum & 4.00 & 4.00 & 8.00 & 8.00 & 7.00 & 7.00 & 7.00 & 6.00 \\
\hline Count & 12.00 & 20.00 & 10.00 & 17.00 & 10.00 & 15.00 & 7.00 & 9.00 \\
\hline
\end{tabular}

Note. Data generated for the weight of Rainbow land crabs from the observational research in 2016 by the authors

The average weight of a female Rainbow land crab after three months was 5.3 pounds with a minimum weight of 4.0 pounds and a maximum weight of 7.0 pounds with majority of the females weighing 5.0 pounds. The average weight of a male Rainbow Land crab then was 5.7 pounds with the heaviest male weighting 7.0 pounds and the list weighting 4.0 pounds. However, majority of the males weighed 6.0 pounds. The average weight of a female Rainbow land crab after the final reading was 5.4 pounds with a minimum weight of 5.0 pounds and a maximum weight of 6.0 pounds with majority of the females weighing 5.0 pounds. The average weight of a male Rainbow land crab then was 5.7 pounds with the heaviest male weighting 7.0 pounds and the list weighting 5.0 pounds. However, majority of the males weighed 5.0 pounds after five months. 


\section{Macrothink}

It can be observed from the results that initially on average, the male Rainbow land crabs weighed more than the females. The weight gain was generally rapid in the first month as compared to subsequent months. This could be due to loss of appendages in the case of some of the crabs and also due to the females releasing their eggs. It was also observed that a female Rainbow land crab shed its carapace.

In the case of the Blue land crabs, out of 20 land crabs, only one female survived and later died after three weeks. It weighed 2pounds.The Rainbow land crabs were housed in the wooden structure and the blue land crabs where housed in the pot.It was observed that the pot retained more heat than the wooden structure serving as a factor that caused the death of the Blue land crabs within one week on arrival at the study site.

The only female Blue land crab that survived carried eggs in its apron. In the case of the Rainbow land crabs, after a month in confinement, four females Rainbow land crabs out of 15 were observed as carrying dark masses in their aprons. The first female to be observed carrying eggs was on $3^{\text {rd }}$ may, 2016. On the $19^{\text {th }}$ of June, one female Rainbow land crab released its eggs into the sea water provided in the shallow plastic containers. By the $26^{\text {th }} \mathrm{June}$, all four females had released their eggs. Whitish membranes were observed a week after the females had released their eggs. Larvae-like creatures were also observed swimming in the sea water provided. On the $6^{\text {th }}$ of May, the number of larvae-like population in the sea water reduced. By $14^{\text {th }}$ June, all movement in the sea water seized. After $1^{\text {st }}$ July, the sea water was discarded and replaced with fresh sea water.The study eventually folded up in December, 2016.

Rainbow land crabs exposed to day light for two months resulted in cannibalism among the crabs. It was mostly the females that lost their limbs. Out of 16 crabs (9 females and 7 males), 7 females lost their limbs ranging from between 1 to 5 limbs. It was also observed that the exposure to day light dulled the colors of the crabs' carapace and the crabs that were not able to find hide-outs, were sluggish. Three days after crabs were left in the dark, they became more active.

\section{Conclusion and Recommendations}

Based on the results, the study concludes that a wooden housing structure is more appropriate for crab rearing. The Rainbow land crabs have been found to be the best species that can be reared in confinement since they performed better than the Blue land crabs in the study. The Rainbow land crabs can be reared in close proximity for a minimum period of five months if the confined area is darkened and hideout accessories provided. The crabs in confinement can be fed on a range of diets, from fish, vegetables to leftovers from the kitchen even though, the study had shown that they prefer sugar cane, palm fronds and palm fruits. The female Rainbow land crabs are capable of spawning in confinement when provided with the right conditions and environment and thus has the tendency to reproduce.

A challenge faced during the study was the limited volume of sea water and conditions required to sustain the development of the land crab hatchlings. It is therefore recommended that, the study be repeated, creating an environment close to the required conditions needed to 
sustain the development of the land crab hatchlings to observe if the hatchlings will develop to the maturity stage. A study should also be carried out to identify challenges and opportunities in land crab farming by locating and interviewing farmers and traders who are already in the venture. The study, finally, recommend Rainbow land crab as a more robust specie that can withstand stressful conditions and suitable for land crab farming.

\section{Acknowledgements}

The authors are especially indebted to Oswald Senyo Atutonu, an Agricultural Engineer for his financial and technical support and Ida Aku Kugblenu a student of Community Eleven Complex School, Tema, Ghana. The authors are also grateful to the respondents and the anonymous reviewers who reviewed the paper.

\section{References}

Adedeji, O. B., Okerentugba, P. O., Innocent-Adiele, H. C., Okonko, I. O., Ojeniyi, S. O., Adejoro, S. A., \& Mohamed, S. A. (2012). Benefits, public health hazards and risks associated with fish consumption. New York Science Journal, 5(9), pp.33-61.

Advanced Vivarium Systems. (2011). The Care of Land Hermit Crabs by Philippe de Vosjoli BVP.

Alves, R. R., Nishida, A. K., \& Hernández, M. I. (2005). Environmental perception of gatherers of the crab'caranguejo-uçá'(Ucides cordatus, Decapoda, Brachyura) affecting their collection attitudes. Journal of Ethnobiology and Ethnomedicine, 1(1), 10.

Amadi, V. A., Peterson, R., Matthew-Belmar, V., Sharma, R., \& Hariharan, H. (2015). Prevalence and antibiotic susceptibility of Gram-negative aerobic bacteria cultured from the intestine and hepatopancreas of blue land crab (Cardisoma guanhumi) in Grenada, West Indies. Microbiology Research Journal International, 169-179. https://doi.org/10.9734/BMRJ/2015/13620

Anonymous (2003). Great Land Crab (On-line). eNature.com. Retrieved December 04, 2004, from

http://www.enature.com/fieldguide/showSpeciesSH.asp?curGroupID=8\&shapeID=1063\&cur PageNum $=6 \&$ recnum $=\mathrm{SC} 0010$

Bliss, D. E. (1979). From sea to tree: saga of a land crab. American zoologist, 19(2), 385-410. https://doi.org/10.1093/icb/19.2.385

Blue Land Crabs Draft Rule Review. Tallahassee, FL: Division of Marine Fisheries. 2002. Retrieved from http://www.floridaconservation.org/commission/2002/nov/LANDCRABDRAFTRULEREVI EW.pdf.

Burggren, W., \& McMahon, B. (1988). Biology of the Land Crabs. New York: Cambridge University Press. https://doi.org/10.1017/CBO9780511753428

Carney, J. A. (2016). Between Land and Sea: Mangroves and Mollusks along Brazil's Mangal 


\section{Ml Macrothink}

Coast. Fronteiras: Journal of Social, Technological and Environmental Science, 5(3), 17-38. https://doi.org/10.21664/2238-8869.2016v5i3.p17-38

Chinabut, S., Somsiri, T., Limsuwan, C., \& Lewis, S. (2006). Problems associated with shellfish farming. Rev. sci. tech. Off. int. Epiz, 25(2), 627-635. https://doi.org/10.20506/rst.25.2.1688

De Leeuw, J., Carsan, S., Koech, G., Yayé, A. D., \& Nyongesa, J. (2017). A review of best practices for selected biodiversity-based value chains that promotes pro-poor conservation in the Horn of Africa.

Dessouassi, C. E., Chikou, A., Lederoun, D., Adandedjan, D., Gangbe, L., \& Laleye, P. (2018). Diversity, biology and exploitation of brackish water crabs in West Africa: A review. International Journal of Biological and Chemical Sciences, 12(5), 2355-2370. https://doi.org/10.4314/ijbcs.v12i5.34

Dessouassi, C. E., Chikou, A., Lederoun, D., Adandedjan, D., Gangbe, L., \& Laleye, P. (2018). Diversity, biology and exploitation of brackish water crabs in West Africa: A review. International Journal of Biological and Chemical Sciences, 12(5), 2355-2370. https://doi.org/10.4314/ijbcs.v12i5.34

Douglas R. M. (2000). Presented for your approval: The Hermit Crab" Critters USA magazine Annual Issue.

Edéa, O. G., Gbangboché, A. B., Hinvi, L. C., \& Azando, E. V. (2015). Breeding of the land crab Cardiosomaarmatum (Herklots 1851) in enclosure in Benin. Journal of Applied Biosciences, 96, 9102 - 9108. https://doi.org/10.4314/jab.v96i1.7

Edéa, O. G., Gbangboché, A. B., Hinvi, L. C., \& Azando, E. V. (2015). Breeding of the land crab Cardiosoma armatum (Herklots 1851) in enclosure in Benin. Journal of Applied Biosciences, 96, 9102-9108. https://doi.org/10.4314/jab.v96i1.7

Galli, O. B., Fujimoto, R. Y., \& Abrunhosa, F. A. (2012). Acute toxicity of sodium metabisulphite in larvae and post-Larvae of the land crab, Cardisoma guanhumi. Bulletin of environmental contamination and toxicology, 89(2), 274-280. https://doi.org/10.1007/s00128-012-0687-7

GREENAWAY, P., Bonaventura, J., \& Taylor, H. H. (1983). Aquatic gas exchange in the freshwater/land crab, Holthuisana transversa. Journal of experimental biology, 103(1), 225-236.

Hartnoll, R. G., Régnier-McKellar, C., Weber, N., \& Weber, S. B. (2014). Return to the land; the stages of terrestrial recruitment in land crabs. Crustaceana, 87(5), 531-539. https://doi.org/10.1163/15685403-00003294

Hill, K. (2001). Cardisoma guanhumi (On-line). Retrieved December 04, 2004, from http://www.sms.si.edu/IRLSpec/Cardis_guanhu.html

Jeebhay, M. F., Lopata, A. L., \& Robins, T. G. (2000). Seafood processing in South Africa: a 
study of working practices, occupational health services and allergic health problems in the industry. Occupational medicine, 50(6), 406-413. https://doi.org/10.1093/occmed/50.6.406

Johnson, D. S. (1965). Land Crabs. Journal of the Malaysian Branch of the Royal Asiatic Society, 38(2), 43-66.

Liu, Q., Xu, X., Zeng, J., Shi, X., Liao, Y., Du, P., Tang, Y., Huang, W., Chen, Q. and Shou, L., 2019. Heavy metal concentrations in commercial marine organisms from Xiangshan Bay, China, and the potential health risks. Marine pollution bulletin, 141, 215-226. https://doi.org/10.1016/j.marpolbul.2019.02.058

Lloyd, R. (2001). The Illusive Great Land Crab (On-line). Retrieved December 04, 2004, from http://www.mhhe.com/biosci/pae/marinebiology/casestudies/case_01.mhtml.

Malleo, J. (2011). ECONOMICS OF MUD CRABS FARMING IN PANGANI (Doctoral dissertation, University of Dar-es-salaam).

Marichamy, R. (1996). Crab farming potential in India. In Proceedings of the Seminar on Fisheries-A Multibillion Dollar Industry, Madras, Aug 17-19, 1995 (pp. 115-122). Aquaculture Foundation of India \& The Fisheries Technocrats Forum.

Mbeh, G. M., Kamga, F. T., Kengap, A. K., Atem, W. E., \& Mbeng, L. O. (2019). Quantification of heavy metals ( $\mathrm{Cd}, \mathrm{Pb}, \mathrm{Fe}, \mathrm{Mg}, \mathrm{Cu}$, and $\mathrm{Zn}$ ) in seafood (fishes and crabs) and evaluation of health risks to consumers in Limbe, Cameroon.

Oduro, W., Ellis, W. O., Oduro, I., \& Tetteh, D. (2001). Nutritional quality of selected Ghanaian crab species. https://doi.org/10.4314/jgsa.v3i3.17763

Petersen, E. H., Suc, N. X., Thanh, D. V., \& Hien, T. T. (2011). Bioeconomic analysis of extensive mud crab farming in Vietnam and analysis of improved diets. Aquaculture Economics \& Management, 15(2), 83-102.

Pinder, A., \& Smits, A. (1993). The Burrow Microhabitat of the Land Crab Cardisoma guanhumi: Respiratory/Ionic Conditions and Physiological Responses of Crabs to Hypercapnia. Physiological Zoology, 216-236. https://doi.org/10.1086/physzool.66.2.30163687

Richard, G. H., Annette, C. B., Brendan, J. G., Susanna, M., Mark, P., Stedson, A. S., Kate, E. S. (2010). Reproduction in the Land Crab Johngarthia Lagostoma on Ascension Island. Journal of Crustacean Biology, 30(1), 83-92. https://doi.org/10.1651/09-3143.1

Salam, M. A., Islam, S. M. M., Gan, J., \& Ross, L. (2012). Crab culture potential in southwestern Bangladesh: alternative to shrimp culture for climate change adaption. International Research Journal of Applied Life Sciences, 1(4), 15-31

Salam, M. A., Ross, L. G., \& Beveridge, C. M., (2003). A comparison of development opportunities for crab and shrimp aquaculture in southwestern Bangladesh, using GIS modelling. Aquaculture, 220(1-4), 477-494. https://doi.org/10.1016/S0044-8486(02)00619-1

Sathiadhas, R., \& Najmudeen, T. M. (2004). Economic evaluation of mud crab farming under 


\section{Macrothink}

different production systems in India. Aquaculture Economics \& Management, 8(1-2), 99-110.

Thomassen, M. R. (2017). Occupational exposure, respiratory health and sensitisation among crab processing workers. A study among processors of king crab (Paralithodes camtschaticus) and edible crab (Cancer pagurus) in Norwegian land based crab processing plants.

Wang, P., Lu, Y., Su, H., Su, C., Johnson, A.C., Yu, L., \& Jenkins, A. (2020). Managing health risks of perfluoroalkyl acids in aquatic food from a river-estuary-sea environment affected by fluorochemical industry. Environment International, 138, p.105621.

Watts, A. J., Urbina, M. A., Corr, S., Lewis, C., \& Galloway, T. S. (2015). Ingestion of plastic microfibers by the crab Carcinus maenas and its effect on food consumption and energy balance. Environmental Science \& Technology, 49(24), 14597-14604. https://doi.org/10.1021/acs.est.5b04026

Zhang, W., Guo, Z., Song, D., Du, S., \& Zhang, L. (2018). Arsenic speciation in wild marine organisms and a health risk assessment in a subtropical bay of China. Science of the Total Environment, 626, 621-629. https://doi.org/10.1016/j.scitotenv.2018.01.108

\section{Copyright Disclaimer}

Copyright for this article is retained by the author(s), with first publication rights granted to the journal.

This is an open-access article distributed under the terms and conditions of the Creative Commons Attribution license (http://creativecommons.org/licenses/by/4.0/). 